\title{
ACTIVATION OF DENTAL INFECTIONS BY CORTISC
STUDIES IN CHILDREN WITH RHEUMATIC FEVER
}

\author{
BY \\ R. C. W. DINSDALE \\ Sutherland Dental School, King's College, Newcastle-upon-Tyne \\ formerly of the Charles Clifford Dental Hospital, Sheffield \\ AND \\ K. S. HOLT \\ Department of Child Health, University of Sheffield
}

During a study of factors influencing the rebound phenomenon in rheumatic fever, a high incidence of infections, especially the dental abscess, was found in children treated with cortisone or corticotrophin (Holt, 1956). These dental lesions showed several unusual features, and so that more could be learnt about them and their relationship to the rebound phenomenon, 34 children treated for rheumatic fever since January, 1956, were observed carefully. These children were a consecutive unselected series of patients admitted to the Children's Hospital, Sheffield, under the care of Professor R. S. Illingworth. None was specifically referred because of dental trouble as well as rheumatic fever. No child who satisfied the criteria for the diagnosis of rheumatic fever and received treatment was omitted from this study.

There were fifteen boys and nineteen girls, aged from 5 to 14 years. Cortisone was given to all the children in the following dosage:

\begin{tabular}{r|c}
\hline \multicolumn{1}{|c|}{ Day } & Amount (mg./day) \\
\hline 1 & 300 \\
$2-4$ & 200 \\
$5-21$ & 100 \\
$22-55$ & 75 \\
$26-90$ & 50 \\
\end{tabular}

26 of the children also received salicylates. Treatment with cortisone or with cortisone and salicylates was continued until the erythrocyte sedimentation rate (E.S.R.), determined weekly, had been normal for three consecutive readings. The duration of treatment varied between 3 and 7 weeks in 32 cases, but the other two children were treated for 13 weeks. This form of therapy for rheumatic $\mathrm{O}$ fever is discussed more fully elsewhere (Illingworth, Lorber, Holt, and Rendle-Short, 1957). The duration of treatment did not appear to influence the lesions described below and is not considered further.

The detailed observations that have now been completed on these 34 children form the basis of the present report.

\section{The Dental Lesion}

Either during or within a few days of the end of cortisone treatment activation of an already existing periodontal lesion was frequently observed. This occurred particularly where there was advanced caries with the loss of vitality of the tooth, or where there was a loose deciduous tooth with deep periodontal pockets. These activated lesions differed from the usual periapical or periodontal abscess in that pain was slight or absent and swelling was less marked than expected. If swelling was present it was confined to the immediate area of the alveolus and buccal sulcus. In no case was a spread beyond the area with an associated cellulitis observed. Local lymph-node enlargement was detected in only two of the six children developing abscesses. In some of the children the only clinical sign was a flood of pus from the neck of a loose deciduous tooth on pressure - a sign easily missed in a casual examination of the mouth. The condition which we observed is well illustrated by the following case.

\section{Case Report}

A girl aged 12 years was admitted to hospital with fever, malaise, and pain in the right knee of one week's duration. She had had tonsillitis a week earlier.

She looked an ill child. Her temperature on admission 
was $100^{\circ} \mathrm{F}$. The right knee was swollen and painful to move and to touch. There was a coarse Grade III systolic murmur and a diastolic murmur at the apex of the heart. The electrocardiogram was normal. The throat swab did not show haemolytic streptococci, but the antistreptolysin-O titre was 450 units $/ \mathrm{ml}$. The E.S.R. was $65 \mathrm{~mm}$. in the first hour (microWestergren), the $\mathrm{C}$-reactive protein $5+$, the mucoprotein tyrosine $13.6 \mathrm{mg} . / 100 \mathrm{ml}$., and the haemoglobin $9.9 \mathrm{~g} . / 100 \mathrm{ml}$.

She was treated with cortisone and salicylates in high doses. Penicillin was given intramuscularly to eliminate streptococci and then continued orally as a prophylactic. The response was good; after 14 days the E.S.R. was normal $(7 \mathrm{~mm} . / \mathrm{hr})$ and treatment was stopped after 28 days. A week later the E.S.R. rose to $20 \mathrm{~mm} . / 1 \mathrm{hr}$ and this coincided with the peak of activation of the dental lesion. Dental extractions were performed and the E.S.R. returned to normal and remained so. The initial dental examination had shown that several deciduous teeth were still present. The radiograph of the lower right first and second deciduous molars is typical of the condition found in these areas (Figure).

One week after admission the alveolus around these teeth became red and oedematous, though the patient complained only once of pain on chewing. These teeth gradually loosened until they could be rocked to and fro, and with each movement a small bead of pus extruded. The organisms isolated from this pus were Streptococcus viridans and Neisseria.

The 34 children studied were placed into three groups according to their dental condition:

(1) The teeth of eleven children were virtually caries free; there were no deep periodontal pockets and the gingivae were pink, firm, and well attached.

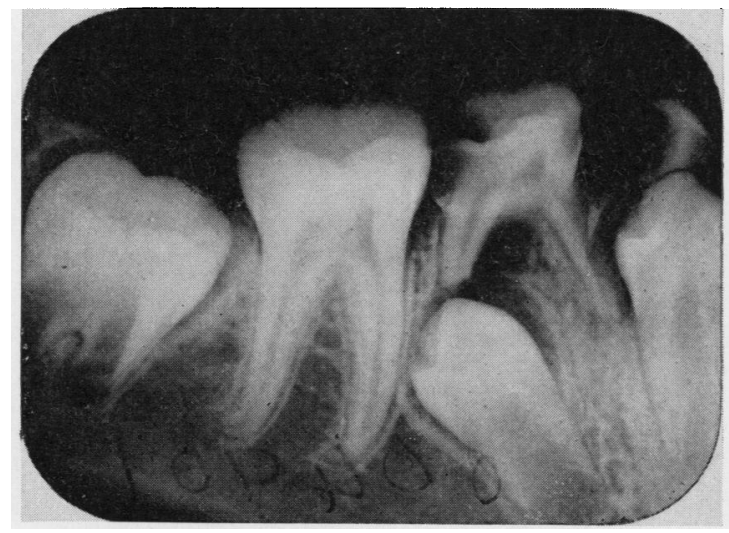

Figure.--Radiograph of lower right first and second deciduous molars.

(2) Four children had deep cavities but their teeth responded to the usual tests for vitality (white and not grey in appearance; sensitive to cold as tested by ethyl chloride and to heat). In doubtful cases a radiograph was taken to assist diagnosis.

(3) There were nineteen children with dead teeth. Four of these had dental extractions early in the course of treatment to prevent dental lesions, and six of the remaining fifteen children ( 4 girls and 2 boys) developed abscesses either during cortisone treatment or within 2 weeks of stopping it (40 per cent.). These cases are summarized in Table $I$; in four of them the deciduous teeth had been retained longer than usual and the abscess appeared in the areas of extensive root resorbtion, and in the other two the lesion was periapical.

TABLE I

SIX CHILDREN WHO DEVELOPED DENTAL LESIONS

\begin{tabular}{|c|c|c|c|c|c|c|}
\hline $\begin{array}{l}\text { Case } \\
\text { Number }\end{array}$ & $\begin{array}{c}\text { Age } \\
\text { (yrs) }\end{array}$ & Sex & $\begin{array}{c}\text { Initial } \\
\text { Examination }\end{array}$ & $\begin{array}{l}\text { Site of } \\
\text { Abscess }\end{array}$ & Treatment & Comments \\
\hline $\begin{array}{l}1 \\
\text { (described } \\
\text { in text) }\end{array}$ & 11 & $\mathbf{F}$ & $\frac{\mathrm{ED} \mid}{\mathrm{ED} \mid \mathrm{DE}} \begin{array}{c}\text { Overlong retention of } \\
\text { deciduous teeth }\end{array}$ & $\overline{\mathrm{ED}}$ & $\frac{\mathrm{ED} \mid}{\mathrm{ED} \mid \mathrm{DE}}$ extracted & $\begin{array}{c}\text { Pus-Strep. viridans } \\
\text { Neisseria }\end{array}$ \\
\hline 2 & 7 & $\mathbf{M}$ & $\frac{\mid \mathrm{D}}{\mathrm{E} \mid \mathrm{D}}$ Carious and non-vital & $\overline{\mathbf{E}}$ & $\frac{\mid D}{E} \mid D$ removed & $\begin{array}{l}\text { Pus-Haemophilus } \\
\text { Strep. viridans } \\
\text { Neisseria }\end{array}$ \\
\hline 3 & 9 & $\mathbf{F}$ & $\begin{array}{l}\text { Ten carious teeth } \\
\text { E D | non-vital }\end{array}$ & $\underline{E} \mathbf{D}$ & E D | extracted & \\
\hline 4 & $8 \frac{1}{2}$ & $\mathbf{F}$ & \begin{tabular}{l|l} 
ED & CDE carious \\
$6 \mathrm{ED}$ & $\mid \mathrm{DE} 6$
\end{tabular} & 61 & 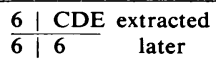 & \\
\hline 5 & $9 \frac{1}{2}$ & $\mathbf{M}$ & $\begin{array}{l}1 \text { fractured, now dead and with } \\
\text { bone loss at apex on radio- } \\
\text { graph }\end{array}$ & 1 & 11 removed & $\begin{array}{l}\text { Pus-Strep. viridans } \\
\text { Neisseria } \\
\text { S. albus (coag. -ve) }\end{array}$ \\
\hline 6 & $13 \frac{1}{2}$ & $\mathbf{F}$ & \begin{tabular}{l|ll}
6 & 6 & dead \\
6 & 6 & No bone change at apex
\end{tabular} & $\frac{616}{1}$ & \begin{tabular}{l|l}
6 & 6 \\
6 & 6
\end{tabular} & $\begin{array}{l}\text { Pus from | } 6 \text { Strep. viridans } \\
\text { Neisseria } \\
\text { Pus from } 6 \text { | Diphtheroids. } \\
\text { Neisseria }\end{array}$ \\
\hline
\end{tabular}


Case 5 is interesting in that the abscess developed in relation to a dead and previously fractured tooth.

The absence of pain with these dental abscesses was very noticeable and was probably due to the facilitation by the cortisone of the diffusion of the infection. Salicylates may also have helped to suppress the symptoms in those children receiving them. The dental lesions were not prevented, however, by the oral penicillin that was given routinely to all the children in treatment of their rheumatic fever.

There is no reason to suppose that this action of cortisone on the dental lesions is limited to children with rheumatic fever. In fact we have seen an identical reaction in a child receiving cortisone for nephrosis.

\section{Dental Abscesses and the Erythrocyte Sedimentation Rate}

Our attention was originally drawn to the activated dental lesions during a search for causes of the raised sedimentation rate so often observed after the end of cortisone therapy in rheumatic fever. It was then necessary to know whether a relatively small septic lesion could produce this systemic disturbance. The available evidence suggested that it could not do so. Rault (1930) had reported that 85 per cent. of 300 patients with periodontal infections had a raised E.S.R., but this could not be supported by Allard, Ralston, and Ralston (1931) or by Cutler (1932). Lintz (1934) studied the E.S.R.s of 27 patients with periodontal infection, as shown by radiographs or by the presence of an abscess following extraction; 25 of the 27 patients are of particular interest, for their ages ranged from 5 to 15 years. Only one of the 25 had a high E.S.R. (Rourke and Ernstene method).

We were able to confirm by studies on children attending the Charles Clifford Dental Hospital, Sheffield, that periodontal infections in normal children seldom affect the E.S.R. These children were selected at random, and the E.S.R. (micro Westergren) was performed as they were anaesthetized before an extraction. In only ten out of 63 children examined was the E.S.R. raised; it was over $20 \mathrm{~mm}$./hr in eight, and over $30 \mathrm{~mm}$. in two. These ten children had particularly severe lesions, and the E.S.R. was often normal in the presence of acute periodontal infection, and even when raised it did not usually reach the levels often seen in the rebounds of rheumatic fever.

There appeared, however, to be a close association between the elevation of the E.S.R. and the activated dental lesions in the cases under discussion. In all the 34 children, except two who had dental abscesses, the E.S.R. settled quickly and remained normal throughout cortisone treatment. In Case 5 the $\frac{}{\omega}$ E.S.R. became normal within seven days of starting treatment. It became slightly raised on the 24th day and much higher on the 32nd day, but at this time $\overrightarrow{0}$ the dental abscess was detected, and after the tooth $\frac{}{0}$ had been extracted the E.S.R. promptly returned to $\frac{\bar{m}}{7}$ normal. In Case 6 the E.S.R. did not settle to $\mathbb{\mathbb { Q }}$ normal but fluctuated considerably; on the 60th day an acute dental abscess was found and extractions were performed, but the E.S.R. remained $\vec{\circ}$ raised until the 90th day when a boil in the nose $\overrightarrow{\vec{\omega}}$ was found and burst. In this case the picture is not ${ }_{\sigma}^{\omega}$ as definite, but it is possible that the additional septic focus in the nose helped to keep the E.S.R.? high.

In each of the other four children with dental abscesses (Cases 1 to 4), the lesions became active $\vec{\sigma}$ shortly after stopping cortisone therapy and in each o case there was a rebound of the E.S.R. Extractions were performed and the E.S.R. settled rapidly in 0 Cases 1 to 3 , but in Case 4 the rebound was so severe that it was thought to be advisable to give a second course of treatment.

The response of the E.S.R. is related to the dental status in Table II. The association between the $\overrightarrow{0}$ occurrence of a dental abscess and the elevation of the E.S.R. is suggested by the facts that the on two children with elevation of the E.S.R. during treatment had dental abscesses and that all the other four children with dental abscesses had a rebound, whereas in the other groups of children not more than half had a rebound.

TABLE II

RELATIONSHIP BETWEEN DENTAL LESIONS AND COURSE OF ERYTHROCYTE SEDIMENTATION RATE

\begin{tabular}{|c|c|c|c|c|}
\hline \multicolumn{2}{|c|}{ Dental Condition } & $\begin{array}{c}\text { Number } \\
\text { of } \\
\text { Cases }\end{array}$ & $\begin{array}{l}\text { Number } \\
\text { in which } \\
\text { the E.S.R. } \\
\text { failed to } \\
\text { Settle }\end{array}$ & $\begin{array}{l}\text { Number } \\
\text { with } \\
\text { Rebound }\end{array}$ \\
\hline \multicolumn{2}{|c|}{ Minimal Caries .. } & 11 & 0 & 6 \\
\hline \multicolumn{2}{|c|}{$\begin{array}{l}\text { Deep Cavities but No Dead Teeth } \\
\text { Periodontal Condition Good .. }\end{array}$} & 4 & 0 & 2 \\
\hline \multirow{3}{*}{$\begin{array}{c}\text { Non-vital } \\
\text { or Loose } \\
\text { Deciduous } \\
\text { Teeth }\end{array}$} & $\begin{array}{l}\text { Prophylactic } \\
\text { extraction }\end{array}$ & 4 & 0 & 2 \\
\hline & $\begin{array}{l}\text { Developed } \\
\text { abscess }\end{array}$ & 6 & 2 & 4 \\
\hline & Others $\ldots$ & 9 & 0 & 4 \\
\hline
\end{tabular}

If we accept the premise of an association between the activated dental lesions and the raised E.S.R., 
then the response of the E.S.R. is greater than that observed in children without rheumatic fever. The possibility then arises that these children with rheumatic fever were exceptionally sensitive to even minimal stimuli. This suggestion would be compatible with the hypothesis that rheumatic fever is a manifestation of a tuberculin type of hypersensitivity to bacterial allergens (Long, 1954).

In the present small group of cases, over half the children had very carious and dead teeth; 40 per cent. of children with such a dental state can expect the activation of a dental abscess, and it is clearly necessary that they should receive very careful and thorough dental treatment. The timing of this treatment is probably best determined by the individual child's general condition and the facilities available. The need for careful management of children undergoing even minor surgery during or after cortisone therapy must always be remembered. The removal of non-vital and loose deciduous teeth early in the course of treatment with cortisone will prevent the development of dental lesions, but it will not abolish the occurrence of the rebound, which is due to multiple factors. A failure of the E.S.R. to settle and a rebound of the E.S.R. after stopping treatment should always lead to a careful examination of the mouth, particularly for the kind of dental condition described above.

\section{Summary}

A study has been made of the dental state of 34 children with rheumatic fever receiving treatment with cortisone either alone or in combination with salicylates.

Nineteen of the 34 children had carious and dead teeth. Four of these had early dental treatment, but six of the other fifteen developed a dental abscess either during or within 2 weeks of stopping cortisone therapy.

The cortisone appeared to activate a pre-existing periodontal lesion. The abscesses which developed were remarkable for the very few symptoms which they caused.

The relationship between the dental abscess and the erythrocyte sedimentation rate is discussed. Whereas in normal children this is seldom appreciably elevated, it was raised in all the six children in this series when a dental abscess developed.

It is difficult to distinguish the relative importance of the various causes of raised erythrocyte sedimentation rates in children with rheumatic fever, but there did seem to be an association between the dental lesions and a raised erythrocyte sedimentation rate. It is suggested that this may be due to the fact that children with rheumatic fever are particularly sensitive to even minimal stimuli affecting the erythrocyte sedimentation rate.

We are grateful to Prof. R. S. Illingworth, Professor of Child Health, and to Prof. G. L. Roberts, Director of Dental Studies, for allowing us to study children under their care, and for advice and criticism.

\section{REFERENCES}

Allard, H., Ralston, J., and Ralston, H. (1931). Acta med. scand., 74,521 .

Cutler, J.'W. (1932). Amer. J. med. Sci., 183, 643.

Holt, K. S. (1956). Arch. Dis. Childh., 31, 444.

Illingworth, R. S., Lorber, J., Holt, K. S., and Rendle-Short, J. (1957). Lancet, 2, 653.

Lintz, W. (1934). Dental Cosmos, 76, 472 and 1149.

Long, D. A. (1954). Lancet, 1, 529.

Rault, C. V. (1930). Dental Cosmos, 72, 219.

Activation des infections dentaires par la cortisone.

Etudes des enfants atteints de rhumatisme articulaire aigu

RÉSUMÉ

On étudia l'état dentaire de 34 enfants atteints de rhumatisme articulaire aigu et traités par la cortisone seule ou bien associée aux salicylates.

Sur 34 enfants, 19 d'entre eux avaient des dents cariées ou mortes. Quatre d'entre eux avaient reçu un traitement dentaire antérieur, mais six sur les quinze restants ont developpé un abcès dentaire soit pendant le traitement par la cortisone, soit au cours de deux semaines qui ont suivies son interruption.

La cortisone semblait activer une lésion périodontique préexistante. Les nouveaux abcès se caractérisaient par la rareté de symptômes.

On discute les rapports antre les abcès dentaires et la vitesse de sédimentation globulaire. Tandis que chez des enfants normaux elle est rarement trop élevée, chez les six enfants de cette série on a noté son augmentation dès la formation de l'abcès dentaire.

Il est difficil de déterminer l'importance relative de différentes causes de la vitesse de sédimentation globulaire élevée chez des enfants atteints de rhumatisme articulaire aigu, mais il semble bien qu'il y avait un rapport entre les lésions dentaires et la sédimentation plus rapide. Ceci pourrait être dû au fait que les enfants atteints de rhumatisme articulaire aigu sont particulièrement sensibles même à des stimulations minimes affectant les érythrocytes.

Activación de infecciones dentales por la cortisona Estudios en niños con reumatismo poliarticular agudo

\section{SUMARIO}

Se estudió el estado de la dentadura en 34 niños con reumatismo poliarticular agudo, tratados con la cortisona sola o asociada a salicilatos.

De los 34 niños examinados, 19 tuvieron dientes cariados o muertos. Cuatro de estos obtuvieron tratamiento dental anterior, pero seis de los quince restantes formaron un absceso dental sea durante el tratamiento con la cortisona, sea dentro de 2 semanas de su interrupción. 
La cortisona pareció activar una lesión periodóntica preexistente. Los abscesos nuevos se caracterizaron por pocos síntomas.

Se discuten las relaciones entre los abscesos dentales y la velocidad de sedimentación eritrocitaria. Mientras que en niños normales ésta se ve raramente muy elevada, en los seis niños de esta serie se notó su elevación con la formación del absceso dental.
Es difícil determinar la importancia relativa de las causas diferentes de la velocidad eritrocitaria elevada en niños con reumatismo poliarticular agudo, pero una relación entre las lesiones dentales y la sedimentación más rapida parece existir. Esto se puede deber al hecho de que niños con reumatismo poliarticular agudo acusan una sensibilidad particular hasta a estímulos minimos que afectan los eritrocitos. 